\title{
ANALISIS FAKTOR-FAKTOR YANG MEMPENGARUHI PERSEPSI WAJIB PAJAK ATAS PENGGELAPAN PAJAK
}

\author{
Gracia Emmanuella Valentina \\ Amelia Sandra* \\ Program Studi Akuntansi, Institut Bisnis dan Informatika Kwik Kian Gie \\ Jl. Yos Sudarso Kav 87, Sunter, Jakarta 14350
}

\begin{abstract}
Tax is one of the main sources of income and expenditure for the nation of Indonesia. Therefore, every year the Government of Indonesia always tries to increase the amount of tax revenue. However, what happens is there are still some Taxpayers who seek to reduce the amount of tax payable by tax evasion. Tax evasion is an attempt to lighten the tax burden by violating existing laws. Meanwhile, this study aims to determine whether the factors such as equity, Self Assessment System, and service of the tax authorities affect the taxpayer's perception of tax evasion. The data obtained came from a questionnaire filled by 100 Individual Taxpayers Entrepreneurs in the field of Micro, Small and Medium Enterprises in the area of Kelapa Gading. The sampling technique used is Purposive Sampling, while the data analysis technique consists of descriptive statistics, data quality test, classical assumption test, hypothesis test, and multiple linear regression model analysis. The result of this research indicate that equity and service of the tax authorities influence to taxpayer perception on tax evasion, while Self Assessment System has no effect to taxpayer perception on tax evasion.
\end{abstract}

Keywords: Equity, Self Assessment System, Service of The Tax Authorities, and Tax Evasion

\begin{abstract}
ABSTRAK
Pajak merupakan salah satu sumber pendapatan dan belanja negara yang utama bagi bangsa Indonesia. Oleh karena itu, setiap tahunnya Pemerintah Indonesia selalu berusaha untuk meningkatkan jumlah penerimaan pajak. Namun, yang terjadi adalah masih ada sebagian Wajib Pajak yang berusaha untuk mengurangi jumlah pajak yang terutang dengan cara melakukan penggelapan pajak. Penggelapan pajak adalah suatu usaha meringankan beban pajak dengan cara melanggar Undang-Undang yang ada. Adapun, penelitian ini bertujuan untuk mengetahui apakah faktor-faktor seperti keadilan, Self Assessment System, dan pelayanan aparat pajak berpengaruh terhadap persepsi Wajib Pajak atas penggelapan pajak. Data yang diperoleh berasal dari kuesioner yang diisi oleh 100 Wajib Pajak Orang Pribadi Usahawan dalam bidang usaha Mikro, Kecil, dan Menengah di wilayah Kelapa Gading. Teknik pengambilan sampel yang digunakan adalah Purposive Sampling, sedangkan teknik analisis data yang dilakukan terdiri dari statistik deskriptif, uji kualitas data, uji asumsi klasik, uji hipotesis, dan analisis model regresi linier berganda. Hasil dari penelitian ini menunjukkan bahwa keadilan dan pelayanan aparat pajak berpengaruh terhadap persepsi Wajib Pajak atas penggelapan pajak, sedangkan Self Assessment System tidak berpengaruh terhadap persepsi Wajib Pajak atas Penggelapan Pajak.
\end{abstract}

Kata Kunci : Keadilan, Self Assessment System, Pelayanan Aparat Pajak, dan Penggelapan Pajak.

\footnotetext{
*Alamat kini: Institut Bisnis dan Informatika Kwik Kian Gie, Jl. Yos Sudarso Kav 87, Sunter, Jakarta 14350

Penulis untuk Korespondensi: (021) 65307062 Ext. 708. Email: Amelia.sandra@kwikkiangie.ac.id
} 


\section{Pendahuluan}

\section{Latar Belakang}

Pajak merupakan salah satu sumber pendapatan dan belanja negara(APBN) yang utama bagi bangsa Indonesia karena hampir 85\% APBN Pemerintah Indonesia berasal dari sektor pajak(Sumber: Kementerian Keuangan Indonesia). Pajak yang diperoleh akan digunakan oleh Pemerintah Indonesia dalam rangka menyelenggarakan dan menjalankan pembangunan nasional untuk memberikan kemakmuran dan kesejahteraan bagi masyarakat. Salah satu hal penting yang dapat menunjang keberhasilan dalam pemungutan pajak di suatu negara adalah sistem pemungutan pajak. Seiring dengan berjalannya waktu, sejak adanya reformasi di bidang pajak tahun 1983, Indonesia mulai menerapkan Self Assessment System. Dalam sistem ini, Wajib Pajak diberikan wewenang untuk menentukan sendiri besarnya pajak yang terutang(Mardiasmo,2016).

Setiap tahunnya, Pemerintah Indonesia selalu berusaha untuk meningkatkan jumlah penerimaan pajak. Namun pada kenyataannya, yang terjadi adalah masih ada sebagian Wajib Pajak yang berusaha untuk mengurangi jumlah pajak yang terutang. Dalam rangka mengurangi jumlah pajak yang terutang, Wajib Pajak dapat melakukan dua hal, yaitu penghindaran pajak(Tax Avoidance) dan penggelapan pajak(Tax Evasion). Akan tetapi, sulitnya penerapan Tax Avoidance ini membuat seorang Wajib Pajak cenderung untuk melakukan Tax Evasion, yaitu suatu usaha meringankan beban pajak dengan cara melanggar UndangUndang(Mardiasmo,2016:11).

Di Indonesia, kasus penggelapan pajak telah banyak mencuat. Banyaknya kerugian negara yang ditimbulkan akibat adanya kasus penggelapan pajak menjadi isu penting yang menarik perhatian rakyat Indonesia. Penggelapan pajak bisa terjadi karena dipengaruhi oleh beberapa faktor seperti keadilan, sistem perpajakan, diskriminasi, Self Assessment System, pemahaman perpajakan, tarif pajak, pendapatan Wajib Pajak, tingkat inflasi, pelayanan aparat pajak, dan kemungkinan terdeteksi kecurangan. Adapun, keadilan yang dimaksud adalah Wajib Pajak memerlukan perlakuan yang adil dalam hal penyusunan Undang-Undang Pajak, penerapan ketentuan perpajakan, dan penggunaan uang pajak(Siahaan dalam Suminarsasi, 2011:8). Berdasarkan penelitian yang dilakukan oleh Yetmi(2014), keadilan berpengaruh positif terhadap persepsi Wajib Pajak mengenai penggelapan pajak. Sedangkan, menurut Friskianti(2014), keadilan tidak berpengaruh terhadap penggelapan pajak.
Faktor kedua adalah sistem perpajakan. Semakin baik sistem perpajakannya, maka perilaku penggelapan pajak dipandang sebagai perilaku yang tidak etis, sebaliknya semakin tidak baik sistem perpajakannya maka perilaku penggelapan pajak dipandang sebagai perilaku yang cenderung etis(Suminarsasi, 2011:10). Menurut penelitian yang dilakukan oleh Suminarsasi(2011) dan Yetmi(2014), sistem perpajakan berpengaruh positif terhadap etika penggelapan pajak.

Faktor lainnya adalah diskriminasi. Diskriminasi perpajakan dapat berupa peraturan perpajakan yang tidak adil, dalam artian, peraturan tersebut menguntungkan pihak-pihak tertentu, ataupun diskriminasi dari segi perlakuan terhadap seluruh Wajib Pajak(Silaen, 2015:4). Menurut penelitian Silaen(2015), diskriminasi berpengaruh terhadap etika penggelapan pajak. Sedangkan menurut penelitian Suminarsasi(2011), diskriminasi berpengaruh negatif terhadap etika penggelapan pajak.

Self Assessment System juga merupakan salah satu faktor yang mempengaruhi Wajib Pajak dalam melakukan tindakan penggelapan pajak. Self Assessment System adalah suatu sistem pemungutan pajak yang memberi wewenang Wajib Pajak dalam menentukan sendiri jumlah pajak yang terutang setiap tahunnya sesuai dengan peraturan perundangundangan perpajakan yang berlaku(Resmi, 2017:11). Semakin baik pelaksanaan Self Assessment System, maka tindakan penggelapan pajak akan semakin rendah. Namun sebaliknya, semakin buruk pelaksanaan Self Assessment System, maka tindakan penggelapan pajak akan semakin tinggi(Friskianti, 2014). Menurut Friskianti(2014), Self Assessment System tidak berpengaruh terhadap tindakan penggelapan pajak. Sedangkan, menurut Saraswati(2013), Self Assessment System berpengaruh terhadap Tax Evasion.

Selain keadilan, sistem perpajakan, diskriminasi, dan Self Assessment System, pemahaman perpajakan juga termasuk sebagai faktor yang berpengaruh atas Tax Evasion. Pengaruh pemahaman perpajakan dapat dikembangkan dengan melihat seberapa besar ketentuan perpajakan dapat dipahami oleh Wajib Pajak, dimengerti, dan dipatuhi untuk kemudian dilaksanakan. Tujuannya agar harapannya ke depan, praktik penggelapan pajak dapat diminimalisir serendah mungkin dan Wajib Pajak memahami perilaku tersebut melanggar hukum dan tidak etis untuk dilakukan. Hasil penelitian yang dilakukan oleh Rachmadi(2014), pemahaman perpajakan berpengaruh terhadap penggelapan pajak.

Untuk menghitung besarnya pajak yang terutang diperlukan dua unsur, yaitu tarif pajak dan 
dasar pengenaan pajak(Resmi, 2017:13). Dalam penetapan tarif pajak harus berdasarkan keadilan. Jika mereka merasa tarif pajak yang berlaku terlalu tinggi, maka akan berbanding lurus dengan tingkat penggelapan pajak(Ardyaksa, 2014:477). Berdasarkan penelitian yang dilakukan oleh Ardyaksa(2014), tarif pajak tidak berpengaruh terhadap penggelapan pajak.

Penelitian yang dilakukan oleh Tabandeh(2012) menggunakan lima variabel, dua diantaranya adalah pendapatan Wajib Pajak dan tingkat inflasi sebagai variabel yang mempengaruhi tindakan penggelapan pajak. Berdasarkan studi teoritis dan empiris(Tabandeh,2012), peningkatan pendapatan Wajib Pajak dapat mendorong terjadinya kenaikan atau penurunan tindakan penggelapan pajak. Selain itu, tingkat inflasi yang tinggi menyebabkan Wajib Pajak menghindar untuk membayar pajak demi mempertahankan kemampuan daya beli mereka. Hasil dari penelitian yang dilakukannya menunjukkan bahwa pendapatan Wajib Pajak berpengaruh negatif terhadap penggelapan pajak, sedangkan tingkat inflasi berpengaruh positif terhadap penggelapan pajak. Selain itu, penelitian lain yang dilakukan oleh Annan(2013) juga menunjukkan bahwa tingkat inflasi berpengaruh positif signifikan terhadap penggelapan pajak.

Faktor lainnya adalah pelayanan aparat pajak. Peningkatan pelayanan aparat pajak idealnya akan memberikan pengaruh yang signifikan bagi Wajib Pajak untuk tidak melakukan penggelapan pajak dan memandang penggelapan pajak sebagai tindakan ilegal, tidak etis, dan melanggar hukum. Menurut penelitian yang dilakukan oleh Rachmadi(2014), pelayanan aparat pajak berpengaruh negatif terhadap persepsi Wajib Pajak atas perilaku penggelapan pajak. Sedangkan, menurut Yetmi(2014), kualitas pelayanan pajak tidak berpengaruh terhadap persepsi Wajib Pajak mengenai penggelapan pajak.

Selain faktor-faktor yang telah disebutkan diatas, kemungkinan terdeteksi kecurangan juga merupakan faktor yang berpengaruh terhadap penggelapan pajak. Ketika seseorang menganggap bahwa persentase kemungkinan terdeteksinya kecurangan melalui pemeriksaan pajak yang dilakukan tinggi, maka ia akan cenderung untuk patuh terhadap aturan perpajakan. Penelitian yang dilakukan oleh Ayu(2011) menunjukkan bahwa kemungkinan terdeteksi kecurangan berpengaruh negatif terhadap Tax Evasion. Begitu pula dengan hasil penelitian yang didapatkan oleh Pulungan(2015), dimana kemungkinan terdeteksi kecurangan juga berpengaruh positif terhadap penggelapan pajak.
Berdasarkan uraian diatas, maka penulis akan melakukan penelitian dengan judul "ANALISIS FAKTOR-FAKTOR YANG MEMPENGARUHI PERSEPSI WAJIB PAJAK ATAS PENGGELAPAN PAJAK”.

\section{Batasan Masalah}

1. Apakah keadilan mempengaruhi persepsi Wajib Pajak atas penggelapan pajak?

2. Apakah Self Assessment System mempengaruhi persepsi Wajib Pajak atas penggelapan pajak?

3. Apakah pelayanan aparat pajak mempengaruhi persepsi Wajib Pajak atas penggelapan pajak?

\section{Tujuan Penelitian}

1. Untuk menganalisis dan mengetahui pengaruh keadilan terhadap persepsi Wajib Pajak atas penggelapan pajak.

2. Untuk menganalisis dan mengetahui pengaruh Self Assessment System terhadap persepsi Wajib Pajak atas penggelapan pajak.

3. Untuk menganalisis dan mengetahui pengaruh pelayanan aparat pajak terhadap persepsi Wajib Pajak atas penggelapan pajak.

\section{Tinjauan Pustaka}

\section{Teori Persepsi}

Menurut Mulyana(2016:179), persepsi adalah proses internal yang memungkinkan kita memilih, mengorganisasikan, dan menafsirkan rangsangan dari lingkungan kita, dan proses tersebut mempengaruhi perilaku kita.

\section{Pajak}

Pajak menurut Undang-Undang Nomor 16 tahun 2009 Pasal 1 ayat (1) berbunyi, pajak adalah kontribusi wajib kepada negara yang terutang oleh orang pribadi atau badan yang bersifat memaksa berdasarkan Undang-Undang, dengan tidak mendapatkan imbalan secara langsung dan digunakan untuk keperluan negara bagi sebesarbesarnya kemakmuran rakyat.

\section{Penggelapan Pajak}

Menurut Mardiasmo(2016:11), penggelapan pajak adalah suatu usaha meringankan 
beban pajak dengan cara melanggar UndangUndang yang ada.

\section{Keadilan}

Menurut Siahaan(2010) dalam Suminarsasi(2011), aspek keadilan yang perlu diperhatikan antara lain adalah keadilan dalam penyusunan Undang-Undang Pajak, keadilan dalam penerapan ketentuan perpajakan, dan keadilan dalam penggunaan uang pajak. Ada berbagai persepsi yang menyatakan bahwa keadilan pajak belum didistribusikan dan dirasakan secara merata bagi setiap Wajib Pajak, sehingga hal ini menyebabkan mereka enggan untuk membayar pajak karena mereka merasa manfaat yang diterima tidak sebanding dengan jumlah pajak yang telah dibayarkan. Selain itu, apabila menurut persepsi mereka sistem pajak yang berlaku tidak adil, maka akan semakin tinggi kecenderungan mereka untuk melakukan penghindaran pajak, seperti melakukan penggelapan pajak. Adapun, penelitian yang dilakukan oleh Yetmi(2014) menunjukkan bahwa keadilan berpengaruh positif terhadap persepsi Wajib Pajak mengenai penggelapan pajak. Sedangkan, menurut Friskianti(2014), keadilan tidak berpengaruh terhadap penggelapan pajak.

\section{Self Assessment System}

Self Assessment System menurut Kurnia(2013:101) adalah suatu sistem perpajakan yang memberi kepercayaan kepada Wajib Pajak untuk mematuhi dan melaksanakan sendiri kewajiban dan hak perpajakannya. Dengan begitu, bisa saja terjadi kemungkinan Wajib Pajak untuk melakukan penggelapan pajak, seperti tidak membayar pajak dengan jumlah yang seharusnya dibayar. Oleh karena itu, dengan menerapkan Self Assessment System, maka semakin tinggi pula kemungkinan Wajib Pajak untuk melakukan penggelapan pajak. Penelitian yang dilakukan oleh Friskianti(2014) menyatakan bahwa Self Assessment System tidak berpengaruh terhadap tindakan penggelapan pajak. Namun, penelitian yang dilakukan oleh Saraswati(2013) menunjukkan bahwa Self Assessment System berpengaruh terhadap Tax Evasion.

\section{Pelayanan Aparat Pajak}

Supadmi(2009:9) berpendapat jika pelayanan yang berkualitas adalah pelayanan yang dapat memberikan kepuasan kepada pelanggan dan tetap dalam batas memenuhi standar pelayanan yang dapat dipertanggungjawabkan serta harus dilakukan secara terus-menerus. Dalam hal perpajakan, pemberian pelayanan yang baik oleh aparat pajak idealnya akan semakin mendorong Wajib Pajak untuk tidak melakukan penggelapan pajak, karena mereka telah merasa puas dengan pelayanan yang diberikan oleh aparat pajak. Dengan begitu, semakin baik pelayanan aparat pajak, maka akan semakin rendah pula penggelapan pajak yang dilakukan. Berdasarkan penelitian yang dilakukan oleh Rachmadi(2014), pelayanan aparat pajak berpengaruh negatif terhadap persepsi Wajib Pajak atas perilaku penggelapan pajak. Sedangkan, menurut Yetmi(2014), kualitas pelayanan pajak tidak berpengaruh terhadap persepsi Wajib Pajak mengenai penggelapan pajak.

\section{Hipotesis}

$\mathrm{Ha}_{1}$ : Keadilan berpengaruh terhadap persepsi Wajib Pajak atas penggelapan pajak.

$\mathrm{Ha}_{2}$ : Self Assessment System berpengaruh terhadap persepsi Wajib Pajak atas penggelapan pajak.

$\mathrm{Ha}_{3}$ : Pelayanan aparat pajak berpengaruh terhadap persepsi Wajib Pajak atas penggelapan pajak.

\section{Metode Penelitian}

\section{Objek Penelitian}

Objek dalam penelitian ini adalah para Wajib Pajak Orang Pribadi Usahawan(UMKM) yang bertempat tinggal di Kelapa Gading. Data-data yang akan digunakan dalam penelitian ini diperoleh dari hasil pengisian kuesioner oleh para Wajib Pajak yang bersangkutan pada Desember 2017 sampai dengan Januari 2018. 


\section{Variabel Penelitian}

\section{Variabel Dependen}

\section{a. Penggelapan Pajak}

\section{Definisi Operasional Variabel Penggelapan Pajak}

\begin{tabular}{|c|c|c|c|}
\hline Variabel & Dimensi & Indikator & Pernyataan \\
\hline $\begin{array}{l}\text { Penggelapan } \\
\text { Pajak }\end{array}$ & $\begin{array}{l}\text { Tidak mengikuti } \\
\text { aturan perpajakan } \\
\text { yang berlaku. }\end{array}$ & 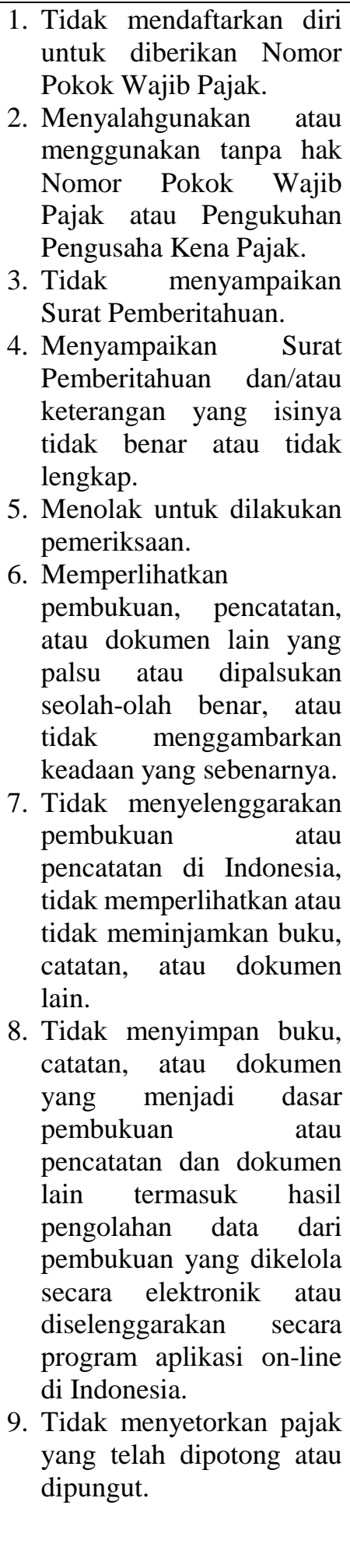 & 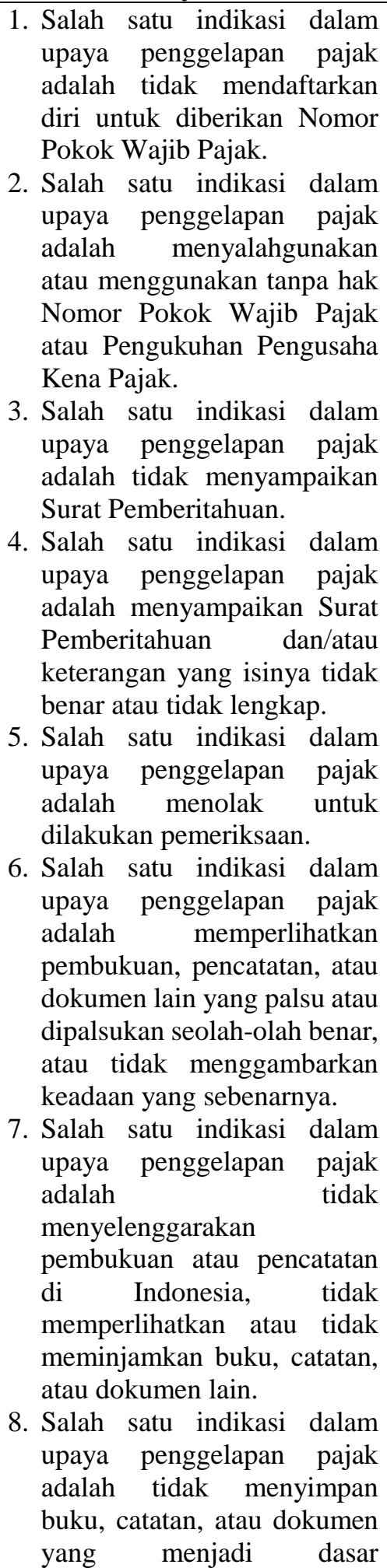 \\
\hline
\end{tabular}




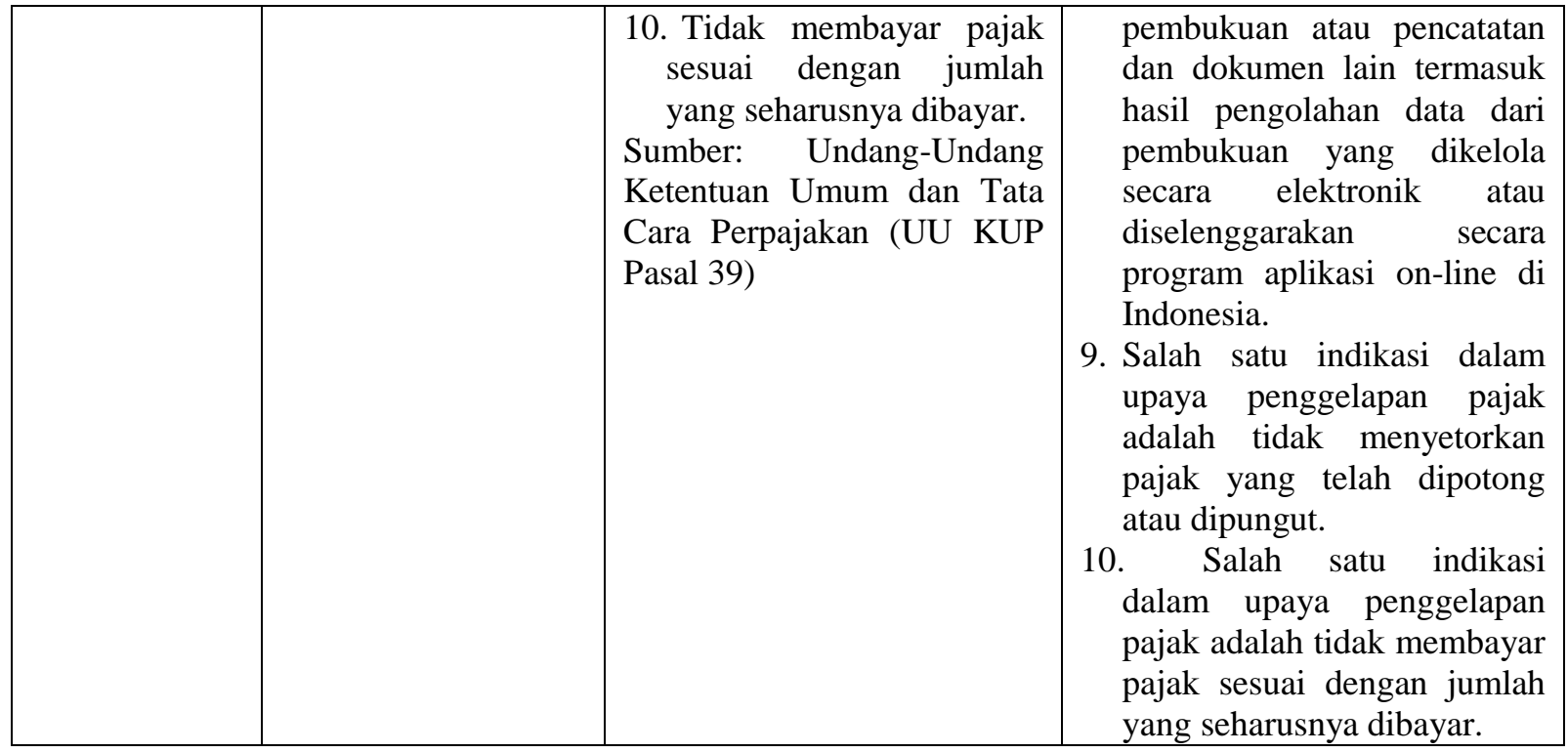

2. Variabel Independen a. Keadilan

Definisi Operasional Variabel Keadilan

\begin{tabular}{|c|c|c|c|}
\hline Variabel & Dimensi & Indikator & Pernyataan \\
\hline $\begin{array}{l}\text { Keadilan } \\
\text { Sumber: } \\
\text { Suminarsasi(2011) }\end{array}$ & $\begin{array}{lr}\text { 1. Cara Mewujudkan } \\
\text { Keadilan Pajak } \\
\text { Sumber: Siahaan(2010) } \\
\text { dalam } \\
\text { Suminarsasi(2011). } \\
\text { Penjelasan lengkap } \\
\text { mengenai indikator dari } \\
\text { dimensi ini diambil dari } \\
\text { Skripsi Irma } & \text { Suryani } \\
\text { Rahman } & \text { dari } \\
\text { Universitas } & \text { Islam } \\
\text { Negeri } & \text { Syarif } \\
\text { Hidayatullah Jakarta. }\end{array}$ & $\begin{array}{l}\text { 1. Adil dalam penyusunan } \\
\text { Undang-Undang Pajak, } \\
\text { yaitu dalam hal penetapan } \\
\text { pungutan wajib yang akan } \\
\text { membebani Wajib Pajak. } \\
\text { 2. Fiskus harus konsisten } \\
\text { dalam menerapkan } \\
\text { ketentuan yang telah } \\
\text { diatur dalam UU Pajak } \\
\text { dengan juga } \\
\text { memperhatikan } \\
\text { kepentingan Wajib Pajak. } \\
\text { 3. Manfaat pajak untuk } \\
\text { pelayanan umum dan } \\
\text { kesejahteraan umum harus } \\
\text { benar-benar mendapatkan } \\
\text { perhatian dan dapat } \\
\text { dirasakan secara langsung } \\
\text { oleh masyarakat yang } \\
\text { menjadi pembayar pajak. }\end{array}$ & $\begin{array}{l}\text { 1. Pemerintah telah adil } \\
\text { dalam menyusun } \\
\text { Undang-Undang Pajak } \\
\text { khususnya dalam hal } \\
\text { penetapan pungutan } \\
\text { wajib yang akan } \\
\text { membebani } \text { Wajib } \\
\text { Pajak. } \\
\text { 2. Fiskus telah konsisten } \\
\text { dalam menerapkan } \\
\text { ketentuan yang telah } \\
\text { diatur dalam UU pajak } \\
\text { serta memperhatikan } \\
\text { kepentingan setiap } \\
\text { Wajib Pajak. } \\
\text { 3. Masyarakat yang } \\
\text { menjadi pembayar pajak } \\
\text { telah benar-benar } \\
\text { merasakan secara } \\
\text { langsung manfaat pajak } \\
\text { berupa pelayanan umum } \\
\text { dan kesejahteraan } \\
\text { umum. }\end{array}$ \\
\hline & $\begin{array}{l}\text { 2. Prinsip Keadilan } \\
\text { Sumber: } \\
\text { Pohan(2014:330) }\end{array}$ & 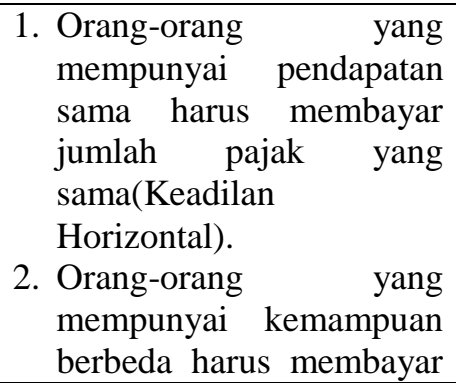 & $\begin{array}{l}\text { 1. Setiap Wajib Pajak yang } \\
\text { mempunyai pendapatan } \\
\text { yang sama, maka } \\
\text { mereka harus membayar } \\
\text { pajak dengan jumlah } \\
\text { yang sama. } \\
\text { 2. Setiap Wajib Pajak yang } \\
\text { mempunyai kemampuan } \\
\text { dalam hal pendapatan }\end{array}$ \\
\hline
\end{tabular}




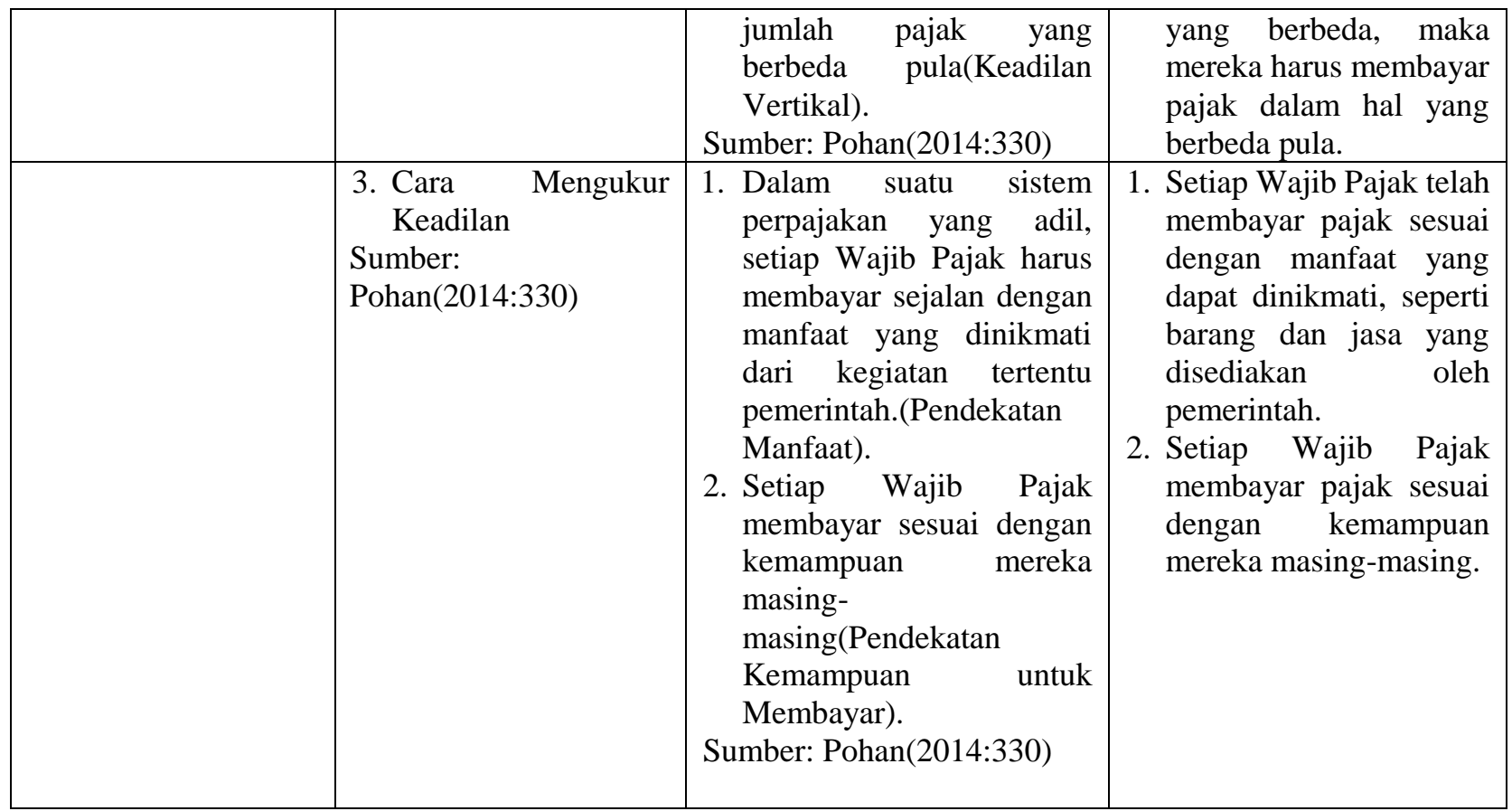

\section{b. Self Assessment System}

Definisi Self Assessment System

\begin{tabular}{|c|c|c|c|}
\hline Variabel & Dimensi & Indikator & Pernyataan \\
\hline $\begin{array}{l}\text { Self Assessment } \\
\text { System } \\
\text { Sumber: } \\
\text { Friskianti(2014) }\end{array}$ & $\begin{array}{l}\text { 1. Kewajiban Wajib } \\
\quad \text { Pajak } \\
\text { Sumber: } \\
\text { Friskianti(2014) }\end{array}$ & $\begin{array}{l}\text { 1. Setiap Wajib Pajak wajib } \\
\text { mendaftarkan diri ke } \\
\text { Kantor } r \text { Pelayanan } \\
\text { Pajak(KPP) atau Kantor } \\
\text { Penyuluhan } \\
\text { Perpajakan(KP4) Potensi } \\
\text { wilayahnya meliputi tempat } \\
\text { tinggal atau kedudukan } \\
\text { Wajib Pajak, dan dapat } \\
\text { melalui e-register(media } \\
\text { elektronik online) untuk } \\
\text { diberikan Nomor Pokok } \\
\text { Wajib Pajak(NPWP). } \\
\text { 2. Setiap Wajib Pajak wajib } \\
\text { menghitung besarnya pajak } \\
\text { terutang yang dilakukan } \\
\text { pada setiap akhir tahun } \\
\text { pajak, dengan cara } \\
\text { mengalihkan tarif pajak } \\
\text { dengan pengenaan } \\
\text { pajaknya. } \\
\text { 3. Setiap Wajib Pajak wajib } \\
\text { membayar sendiri pajak } \\
\text { yang terutang dan } \\
\text { melakukan pembayaran di } \\
\text { bank-bank pemerintah } \\
\text { maupun swasta dan kantor } \\
\text { pos dengan menggunakan } \\
\text { Surat Setoran Pajak atau }\end{array}$ & 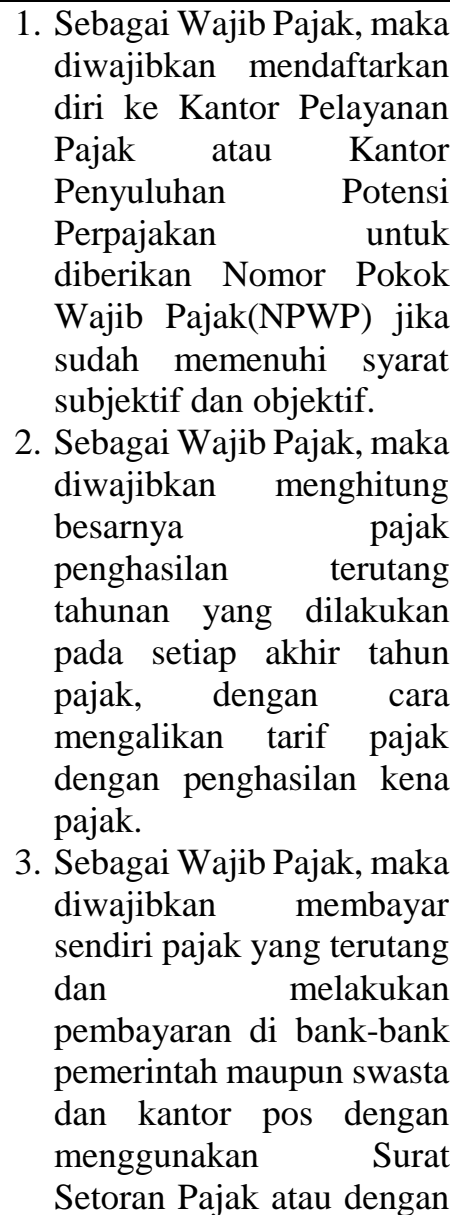 \\
\hline
\end{tabular}




\begin{tabular}{|c|c|c|c|}
\hline & & $\begin{array}{l}\text { dengan cara membayar } \\
\text { pajak secara elektronik. } \\
\text { 4. Setiap Wajib Pajak wajib } \\
\text { melaporkan dan } \\
\text { mempertanggungjawabkan } \\
\text { perhitungan jumlah pajak } \\
\text { yang sebenarnya terutang } \\
\text { dengan menggunakan Surat } \\
\text { Pemberitahuan(SPT). } \\
\text { Sumber: Kurnia(2013) }\end{array}$ & $\begin{array}{l}\text { cara membayar pajak } \\
\text { secara elektronik. } \\
\text { 4. Sebagai Wajib Pajak, maka } \\
\text { diwajibkan melaporkan } \\
\text { dan } \\
\text { mempertanggungjawabkan } \\
\text { perhitungan jumlah pajak } \\
\text { yang sebenarnya terutang } \\
\text { dengan menggunakan } \\
\text { Surat } \\
\text { Pemberitahuan(SPT). }\end{array}$ \\
\hline & $\begin{array}{l}\text { 2. Hak Wajib Pajak } \\
\text { Sumber: } \\
\text { Friskianti(2014) }\end{array}$ & $\begin{array}{l}\text { 1. WP dapat melakukan } \\
\text { pembetulan SPT jika } \\
\text { terdapat kesalahan dengan } \\
\text { syarat belum melampaui } 2 \\
\text { tahun sesudah berakhirnya } \\
\text { tahun pajak dan fiskus } \\
\text { belum melakukan tindakan } \\
\text { pemeriksaan. } \\
\text { 2. WP yang mempunyai } \\
\text { kelebihan pembayaran } \\
\text { pajak dapat mengajukan } \\
\text { permohonan pengembalian. } \\
\text { 3. WP yang merasa tidak puas } \\
\text { atas ketetapan pajak yang } \\
\text { telah diterbitkan dapat } \\
\text { mengajukan keberatan dan } \\
\text { banding. } \\
\text { Sumber: Hartati(2015:140) }\end{array}$ & 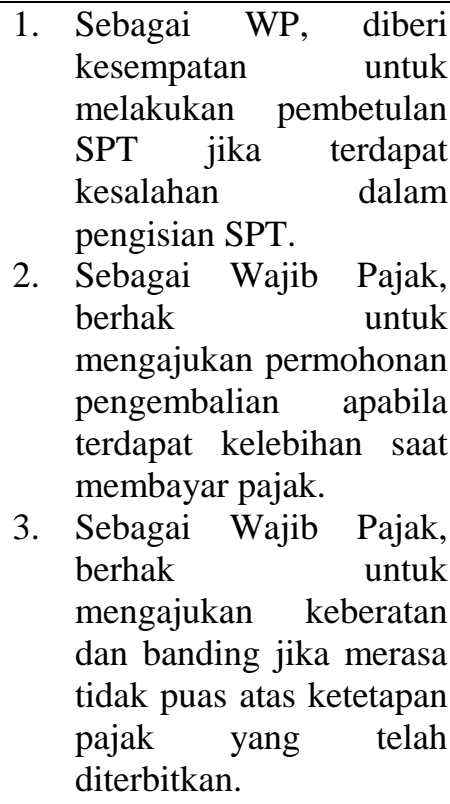 \\
\hline
\end{tabular}

\section{c. Pelayanan Aparat Pajak}

\section{Definisi Operasional Variabel Pelayanan Aparat Pajak}

\begin{tabular}{|c|c|c|c|}
\hline Variabel & Dimensi & Indikator & Pernyataan \\
\hline $\begin{array}{l}\text { Pelayanan Aparat } \\
\text { Pajak } \\
\text { Sumber: } \\
\text { Yetmi(2014) }\end{array}$ & $\begin{array}{l}\text { 1. Pengaturan Jam } \\
\text { Pelayanan }\end{array}$ & $\begin{array}{l}\text { 1. Setiap petugas di Tempat } \\
\text { Pelayanan Terpadu(TPT) } \\
\text { wajib melayani Wajib } \\
\text { Pajak pada jam pelayanan, } \\
\text { yaitu pukul 08.00-16.00 } \\
\text { waktu setempat. } \\
\text { 2. Pemberian layanan di TPT } \\
\text { tetap dilaksanakan pada } \\
\text { jam istirahat. }\end{array}$ & $\begin{array}{l}\text { 1. Dalam meningkatkan } \\
\text { pelayanan prima kepada } \\
\text { Wajib Pajak, maka setiap } \\
\text { petugas di TPT akan } \\
\text { melayani Wajib Pajak pada } \\
\text { jam pelayanan, yaitu pukul } \\
\text { 08.00-16.00 } \\
\text { setempat. } \\
\text { 2. Dalam meningkatkan } \\
\text { pelayanan prima kepada } \\
\text { Wajib Pajak, maka } \\
\text { pemberian layanan di TPT } \\
\text { akan tetap dilaksanakan } \\
\text { meskipun pada jam } \\
\text { istirahat. }\end{array}$ \\
\hline & 2. Sistem Antrean & $\begin{array}{lrr}\text { Petugas } & \text { TPT } & \text { harus } \\
\text { memberikan layanan kepada } \\
\text { Wajib Pajak dan/atau } \\
\text { masyarakat sampai dengan } \\
\text { antrean terakhir. }\end{array}$ & $\begin{array}{l}\text { Dalam meningkatkan } \\
\text { pelayanan prima kepada Wajib } \\
\text { Pajak, maka petugas TPT akan } \\
\text { memberikan layanan kepada }\end{array}$ \\
\hline
\end{tabular}




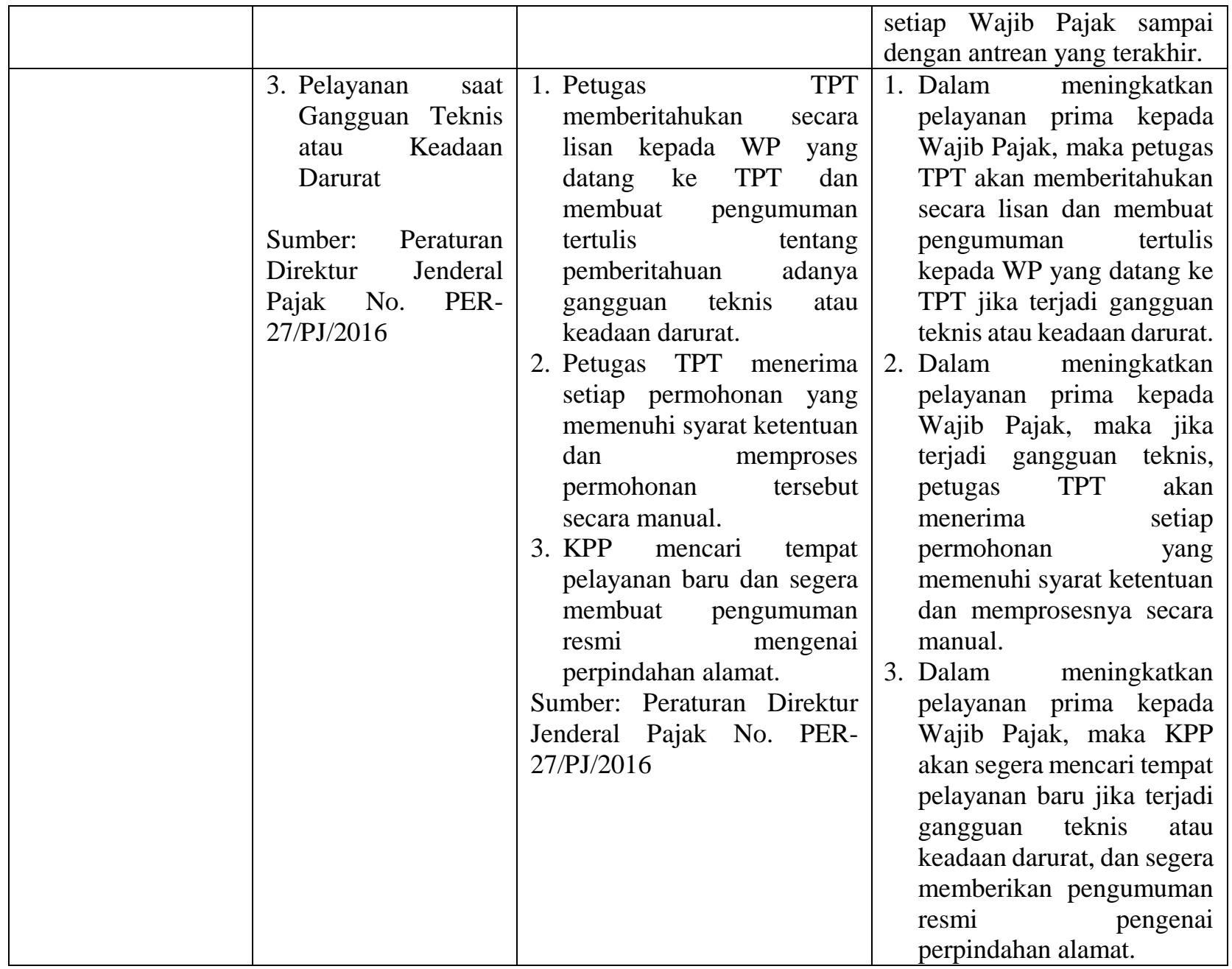

\section{Teknik Pengumpulan Data}

Teknik pengumpulan data dalam penelitian ini dilakukan dengan menggunakan angket/kuesioner. Adapun, kuesioner yang digunakan adalah kuesioner tertutup. Dalam kuesioner tertutup, responden memiliki tugas untuk memilih satu jawaban dari setiap pertanyaan yang telah disediakan(Darmawan, 2016:160).

\section{Teknik Pengambilan Sampel}

Dalam penelitian ini, peneliti menggunakan teknik pengambilan sampel yang disebut dengan Purposive Sampling. Purposive Sampling adalah salah satu teknik pengambilan sampel, dimana responden yang terpilih menjadi anggota sampel atas dasar pertimbangan peneliti sendiri. Sampel yang diambil dalam penelitian ini adalah Wajib Pajak Orang Pribadi Usahawan(UMKM) di wilayah Kelapa Gading. Oleh dikarenakan adanya batasan dalam penelitian ini, maka peneliti hanya mengambil sampel sebanyak 100 responden di wilayah Kelapa Gading yang menurut peneliti telah cukup untuk mewakili seluruh Wajib Pajak Orang Pribadi Usahawan(UMKM) di wilayah Kelapa Gading.

\section{Teknik Analisis Data}

\section{Statistik Deskriptif}

Statistik deskriptif memberikan gambaran atau deskripsi suatu data yang dilihat dari nilai rata-rata(mean), standar deviasi, varian, maksimum, minimum, sum, range, kurtosis dan skewness(kemencengan distribusi)(Ghozali, 2016:19).

\section{Uji Kualitas Data}

\section{a. Uji Reliabilitas}

Reliabilitas sebenarnya adalah alat untuk mengukur suatu kuesioner yang merupakan indikator dari variabel atau konstruk. Suatu kuesioner dikatakan reliabel atau handal jika jawaban seseorang 
terhadap penyataan adalah konsisten atau stabil dari waktu ke waktu(Ghozali,2016:47).

b. Uji Validitas

Uji validitas digunakan untuk mengukur sah atau valid tidaknya suatu kuesioner. Suatu kuesioner dikatakan valid jika pertanyaan pada kuesioner mampu untuk mengungkapkan sesuatu yang akan diukur oleh kuesioner tersebut. Uji validitas ini ingin mengukur apakah pertanyaan dalam kuesioner yang sudah kita buat benar-benar dapat mengukur apa yang hendak kita ukur(Ghozali,2016:52).

\section{Uji Asumsi Klasik}

\section{a. Multikolonieritas}

Uji multikolonieritas bertujuan untuk menguji apakah model regresi ditemukan adanya korelasi antar variabel bebas(independen). Model regresi yang baik seharusnya tidak terjadi korelasi di antara variabel independen(Ghozali, 2016:103). Untuk mendeteksi ada atau tidaknya multikolonieritas di dalam model regresi dapat dilakukan dengan melihat nilai Tolerance dan lawannya yaitu Variance Inflation Factor(VIF). Jika nilai Tolerance $\geq 0,10$ dan $V I F \leq 10$, maka menunjukkan tidak adanya multikolonieritas.

\section{b. Autokorelasi}

Uji autokorelasi bertujuan menguji apakah dalam model regresi linear ada korelasi antara kesalahan pengganggu pada periode $\mathrm{t}$ dengan kesalahan pengganggu pada periode $\mathrm{t}-$ 1(sebelumnya). Jika terjadi korelasi, maka dinamakan ada problem autokorelasi. Model regresi yang baik adalah regresi yang bebas dari autokorelasi(Ghozali,2016:107).

Cara yang digunakan untuk mendeteksi ada atau tidaknya autokorelasi adalah dengan mengunakan uji DurbinWatson(DW test). Jika du $<\mathrm{d}<4$
- du, maka tidak ada autokorelasi, positif atau negatif. Adapun, nilai dl dan du dapat dilihat dari tabel Durbin Watson dengan $\alpha=5 \%$, kemudian dikaitkan dengan $\mathrm{k}$ (jumlah variabel bebasnya) dan n(jumlah sampel).

c. Heteroskedastisitas

Uji heteroskedastisitas bertujuan menguji apakah dalam model regresi terjadi ketidaksamaan variance dari residual satu pengamatan ke pengamatan yang lain. Jika variance dari residual satu pengamatan ke pengamatan lain tetap, maka disebut homoskedastisitas dan jika berbeda disebut heteroskedastisitas(Ghozali,2016: 134). Cara yang digunakan untuk mendeteksi ada atau tidaknya heteroskesdatisitas adalah dengan uji Glejser, yaitu untuk meregres nilai absolut residual terhadap variabel independen(Gujarati 2003 dalam Ghozali 2016). Untuk mengetahui hasilnya, maka kita perlu melihat probabilitas signifikasi yang terdapat pada output pengujian berupa tabel Coefficients. Jika nilai probabilitas signifikansi(Sig) > tingkat kesalahan(5\%), maka model regresi tidak mengandung adanya heteroskedastisitas.

\section{d. Normalitas}

Uji normalitas bertujuan untuk menguji apakah dalam model regresi, variabel pengganggu atau residual memiliki distribusi normal(Ghozali, 2016:154). Cara yang digunakan untuk mendeteksi apakah residual berdistribusi normal atau tidak adalah dengan uji Kolmogorov-Smirnov(Ghozali, 2016:158). Yang harus dilakukan adalah melihat nilai Asymp. Sig. (2-tailed) yang terdapat pada tabel output One-Sample KolmogorovSmirnov Test, kemudian membandingkannya dengan tingkat kesalahan $(\alpha=$ 5\%)(Ghozali, 2016:31). Jika Asymp. Sig. (2-tailed) $>\alpha$, maka data terdistribusi secara normal. 


\section{Uji Hipotesis}

a. Koefisien Determinasi(Adjusted $R^{2}$ )

Koefisien determinasi $\left(\mathrm{R}^{2}\right)$ pada intinya mengukur seberapa jauh kemampuan model dalam menerangkan variasi variabel dependen(Ghozali,2016:95). Nilai koefisien determinasi adalah antara nol dan satu. Nilai $R^{2}$ yang kecil berarti kemampuan variabelvariabel independen dalam menjelaskan variasi variabel dependen amat terbatas. Nilai yang mendekati satu berarti variabel-variabel independen memberikan hampir semua informasi yang dibutuhkan untuk memprediksi variasi variabel dependen.

b. Uji Statistik Fisher(F)

Uji pengaruh simultan digunakan untuk mengetahui apakah variabel independen secara bersama-sama atau simultan mempengaruhi variabel

dependen(Ghozali,2016:171).

Adapun, hasil dari pengujian ini dapat dilihat dari tabel Anova, yaitu dengan melihat kolom Sig(Ghozali, 2016:99). Jika nilai probabilitas signifikansi(Sig) < 0,05 , maka dapat dikatakan bahwa variabel independen secara bersama-sama berpengaruh terhadap variabel dependen.

c. Uji Statistik $\mathbf{t}$

Uji statistik $t$ pada dasarnya menunjukkan seberapa jauh pengaruh satu variabel penjelas/independen secara individual dalam menerangkan variasi variabel dependen(Ghozali,2016:97). Cara untuk melakukan uji $\mathrm{t}$ adalah dengan membandingkan probabilitas signifikansi dengan tingkat kesalahan sebesar 5\%. Nilai probabilitas signifikansi dapat dilihat pada output hasil pengujian, yaitu tabel Coefficients pada kolom Sig. Jika nilai probabilitas signifikansi(Sig) < tingkat kesalahan(5\%), maka variabel terikat dipengaruhi oleh variabel bebas.

\section{Analisis Regresi Linier/ Uji Model}

Analisis regresi linier berganda digunakan untuk mengetahui pengaruh atau hubungan secara linear antara dua atau lebih variabel independen dengan satu variabel dependen. Perbedaan dengan regresi linier sederhana adalah, bahwa regresi linier sederhana hanya menggunakan satu variabel independen dalam satu model regresi, sedangkan regresi linier berganda menggunakan dua atau lebih variabel independen dalam satu model regresi(Priyatno, 2017:169). Dalam penelitian ini, persamaan yang akan digunakan adalah:

$$
\mathrm{Y}=\mathrm{a}+\mathrm{b} 1 \mathrm{X} 1+\mathrm{b} 2 \mathrm{X} 2+\mathrm{b} 3 \mathrm{X} 3+\mathrm{e}
$$

Dimana:

$\mathrm{Y}=$ Penggelapan Pajak

$\mathrm{a}=$ Konstanta

$\mathrm{b}=$ Koefisien Regresi

$\mathrm{X}_{1}=$ Keadilan

$\mathrm{X}_{2}=$ Self Assessment System

$\mathrm{X}_{3}=$ Penggelapan Pajak

$\mathrm{e}=$ Error

\section{Hasil Dan Pembahasan}

\section{Statistik Deskriptif}

a. Keadilan

Hasil statistik deskriptif dari variable Keadilan berupa nilai Minimum, Nilai Maksimum, Rata-rata(Mean) dapat dilihat di lampiran Tabel 1

\section{b. Self Assessment System}

Hasil statistik deskriptif dari variable Self Assessment System berupa nilai Minimum, Nilai Maksimum, Rata-rata(Mean) dapat dilihat di lampiran Tabel 2

\section{c. Pelayanan Aparat Pajak}

Hasil statistik deskriptif dari variable Pelayanan Aparat Pajak berupa nilai Minimum, Nilai Maksimum, Rata-rata(Mean) dapat dilihat di lampiran Tabel 3

\section{d. Penggelapan Pajak}

Hasil statistik deskriptif dari variable Penggelapan Pajak berupa nilai Minimum, Nilai 
Maksimum, Rata-rata(Mean) dapat dilihat di lampiran Tabel 4.

\section{Uji Kualitas Data}

\section{a. Uji Reliabilitas}

Dalam pra kuesioner, peneliti hanya mengambil sebanyak 30 responden berupa Wajib Pajak Orang Pribadi Usahawan(UMKM) di wilayah Kelapa Gading, sedangkan untuk kuesioner peneliti megambil responden sebanyak 100. Adapun, cara yang dilakukan untuk mengetahui apakah variabel tersebut reliabel atau tidak adalah dengan melihat nilai Cronbach Alpha. Jika nilai Cronbanch Alpha $>0,70$, maka pernyataan tersebut dikatakan reliabel. Berdasarkan hasil untuk pra kuesioner, nilai Cronbach Alpha dari setiap variabel lebih besar dari 0,70 . Sehingga, dapat dikatakan bahwa setiap variabel independen dan dependen tersebut bersifat reliabel. Begitu pula dengan hasil uji reliabilitas untuk kuesioner yang menunjukkan bahwa setiap variabel independen dan dependen tersebut bersifat reliabel.

\section{b. Uji Validitas}

Dalam pra kuesioner, peneliti hanya mengambil sebanyak 30 responden berupa Wajib Pajak Orang Pribadi Usahawan(UMKM) di wilayah Kelapa Gading, sedangkan untuk kuesioner peneliti mengambil responden sebanyak 100. Adapun, cara yang dilakukan untuk mengetahui apakah pernyataan tersebut valid atau tidak adalah dengan melihat nilai Corrected Item-Total Correlation( $\mathrm{r}$ hitung) yang terdapat pada output Cronbach Alpha, kemudian membandingkannya dengan $r$ tabel. Jika $r$ hitung $>r$ tabel dan bernilai positif, maka dapat dikatakan bahwa pernyataan tersebut valid. Untuk hasil pra kuesioner, setiap indikator penyataan dari variabel Self Assessment System, pelayanan aparat pajak, dan penggelapan pajak bersifat valid. Namun, untuk variabel keadilan terdapat satu indikator pernyataan, yaitu indikator pernyataan ke-4 yang tidak valid, sehingga pernyataan tersebut tidak akan dijadikan sebagai indikator pernyataan untuk kuesioner. Kemudian, hasil uji validitas untuk kuesioner menunjukkan jika indikator pernyataan dari setiap variabel bersifat valid.

\section{Uji Asumsi Klasik}

a. Uji Multikolonieritas

Berdasarkan hasil uji multikolonieritas (Lampiran : Tabel 5) diketahui bahwa nilai tolerance dari setiap variabel $\geq$ 0,1 dan nilai $V I F$ dari setiap variabel $\leq 10$, sehingga dapat dikatakan bahwa model regresi bebas dari multikolonieritas atau tidak terdapat korelasi antar variabel bebas.

\section{b. Uji Autokorelasi}

Berdasarkan hasil (Lampiran: Tabel 6), diketahui jika nilai Durbin Watson yang diperoleh adalah sebesar 2,130. Jika dilihat dari tabel karakteristik uji autokorelasi, maka dapat dikatakan jika model regresi bebas dari autokorelasi. Hal ini dikarenakan nilai Durbin Watson berada diantara nilai du dan 4-du. Nilai du sendiri dapat diperoleh dari tabel Durbin Watson dengan menggunakan nilai signifikansi $5 \%$, jumlah sampel 100, dan jumlah variabel bebas $3(\mathrm{k}=3)$, sehingga nilai du yang diperoleh sebesar 1,736. Sedangkan, untuk 4-du adalah sebesar 4$1,736=2,264$. Oleh karena itu, hasil keseluruhan yang diperoleh adalah 1,736(du) < 2,130(Durbin Watson) < 2,264(4-du) dan terbukti jika tidak terdapat autokorelasi dalam penelitian ini.

\section{c. Uji Heteroskedastisitas}

Berdasarkan hasil (Lampiran : tabel 7), diketahui bahwa nilai probabilitas signifikansi(Sig) dari 
setiap variabel lebih besar dari 0,05 , sehingga dapat dikatakan jika dalam model regresi tidak mengandung adanya heteroskedastisitas.

d. Uji Normalitas

Berdasarkan Lampiran : Tabel 8 di atas, dapat diketahui jika nilai Asymp. Sig. (2-tailed) yang diperoleh sebesar 0,284 yang artinya > dari 0,05 , sehingga dapat dikatakan jika data terdistribusi secara normal.

\section{Uji Hipotesis}

a. Koefisien

\section{Determinasi}

(Adjusted R ${ }^{2}$ )

Berdasarkan hasil (Lampiran : Tabel 9), diketahui jika nilai Adjusted $R^{2}$ yang diperoleh sebesar 0,176. Hal ini berati variabilitas variabel dependen(terikat) yang dapat dijelaskan oleh variabel independen(bebas) hanya sebesar $17,6 \%$. Sedangkan, sisanya yaitu $82,4 \%$ dijelaskan oleh variabel lain yang tidak digunakan dalam penelitian ini.

b. Uji Statistik Fisher(F)

Berdasarkan hasil (Lampiran : Tabel 10), maka dapat dikatakan bahwa variabel independen berupa keadilan, Self Assessment System, dan pelayanan aparat pajak secara simultan atau bersama-sama mempengaruhi variabel dependen, yaitu penggelapan pajak. Hal ini dikarenakan nilai probabilitas signifikansinya lebih kecil dari 0,05 .

\section{c. Uji Statistik t}

Berdasarkan hasil (Lampiran : Tabel 11) terlihat nilai signifikansi dari ketiga variabel independen tersebut, yakni keadilan, Self Assessment System, dan pelayanan aparat pajak, maka dapat disimpulkan jika variabel dependen berupa penggelapan pajak hanya dipengaruhi oleh keadilan dan pelayanan aparat pajak. Hal ini dikarenakan nilai signifikansi variabel keadilan dan pelayanan aparat pajak lebih kecil dari $0,05, \quad$ sedangkan nilai signifikansi dari variabel Self Assessment System jauh diatas 0,05 .

\section{Analisis Regresi Linier Berganda}

$\begin{array}{rlrr}\text { Jika } & \text { dilihat dari table } & 12 \\ \text { (lampiran), } & \text { maka dapat diperoleh }\end{array}$ persamaan regresi sebagai berikut:

$\mathrm{P}=18,057+0,427 \mathrm{~K}-0,041 \mathrm{SAS}+$ $0,458 \mathrm{PAP}$

Dari persamaan regresi linier berganda di atas, maka dapat dijelaskan bahwa konstanta sebesar 18,057 menyatakan jika variabel independen dianggap konstan, maka penggelapan pajak adalah sebesar 18,057 . Koefisien regresi variabel keadilan sebesar 0,427 menyatakan bahwa jika variabel independen lain nilainya tetap dan variabel keadilan mengalami kenaikan 1\%, maka akan meningkatkan penggelapan pajak sebesar 0,427\%. Koefisien regresi variabel Self Assessment System sebesar 0,041 menyatakan bahwa jika variabel independen lain nilainya tetap dan variabel Self Assessment System mengalami kenaikan 1\%, maka akan mengakibatkan penurunan pada penggelapan pajak sebesar $0,041 \%$. Koefisien regresi variabel pelayanan aparat pajak sebesar 0,458 menyatakan bahwa jika variabel independen lain nilainya tetap dan variabel pelayanan aparat pajak mengalami kenaikan $1 \%$, maka akan meningkatkan penggelapan pajak sebesar $0,458 \%$.

\section{Pembahasan}

1. Pengaruh Keadilan terhadap Persepsi Wajib Pajak atas Penggelapan Pajak

Berdasarkan tabel 11, dapat diketahui jika variabel keadilan memiliki nilai signifikansi sebesar 0,003 yang artinya lebih kecil dari 0,05 . Selain itu, jika dilihat dari analisis model regresi linier berganda, variabel keadilan memiliki koefisien regresi sebesar 0,427 yang menunjukkan arah positif dengan penggelapan pajak. Sehingga, dapat dikatakan bahwa variabel keadilan berpengaruh positif terhadap persepsi Wajib Pajak atas penggelapan pajak. Dengan kata lain, hipotesis yang 
menyatakan bahwa keadilan berpengaruh terhadap persepsi Wajib Pajak atas penggelapan pajak dapat diterima.

Hasil penelitian ini tidak sesuai dengan hasil yang diperoleh oleh Friskianti(2014), yang menyatakan bahwa keadilan tidak berpengaruh terhadap penggelapan pajak. Namun, sejalan dengan hasil yang diperoleh oleh Yetmi(2014) yang menyatakan bahwa keadilan berpengaruh positif terhadap persepsi Wajib Pajak atas penggelapan pajak. Hasil yang diperoleh dalam penelitian ini memang menunjukkan bahwa keadilan berpengaruh positif terhadap penggelapan pajak. Selain itu, jika dilihat dari hasil rata-rata seluruh pernyataan yang ada di uji statistik deskriptif, variabel keadilan memiliki nilai rata-rata 3,95. Hal ini juga menunjukkan bahwa Wajib Pajak tersebut telah berpersepsi bahwa sistem perpajakan yang berlaku sudah adil, namun kenyataannya mereka tetap terindikasi memiliki keinginan untuk melakukan penggelapan pajak. Akan tetapi, secara teori seharusnya keadilan memiliki pengaruh yang negatif terhadap penggelapan pajak. Alasan mengapa terdapat perbedaan dalam hal tersebut mungkin karena Wajib Pajak yang menjadi sampel dalam penelitian ini sudah tidak begitu memperhatikan lagi mengenai keadilan pajak yang terjadi saat ini, apakah keadilan telah didistribusikan dan dirasakan secara merata atau belum, apakah manfaat yang diterima telah sebanding dengan jumlah pajak yang telah dibayarkan atau belum, dan apakah sistem pajak yang berlaku saat ini telah adil atau belum. Menurut teori, jika sistem pajak yang berlaku telah adil, maka akan semakin rendah kecenderungan mereka untuk melakukan penggelapan pajak. Namun, berdasarkan hasil yang diperoleh, yang mungkin terjadi adalah Wajib Pajak tersebut tetap terindikasi memiliki keinginan untuk melakukan penggelapan pajak meskipun sistem pajak yang berlaku saat ini telah adil sekalipun. Hal ini berarti, apapun kondisi yang terjadi, apakah keadilan pajak telah terpenuhi atau belum, Wajib Pajak tersebut tetap akan melakukan tindakan penggelapan pajak dalam rangka memperkecil pajak yang akan mereka bayar.
2. Pengaruh Self Assessment System terhadap Persepsi Wajib Pajak atas Penggelapan Pajak

Berdasarkan tabel 11, dapat diketahui jika variabel Self Assessment System memiliki nilai signifikansi sebesar 0,737 yang artinya lebih besar dari 0,05 . Sehingga, dapat dikatakan bahwa variabel Self Assessment System tidak berpengaruh terhadap persepsi Wajib Pajak atas penggelapan pajak. Dengan kata lain, hipotesis yang menyatakan bahwa Self Assessment System berpengaruh terhadap persepsi Wajib Pajak atas penggelapan pajak tidak dapat diterima atau hipotesis ditolak.

Hasil penelitian ini sesuai dengan hasil yang diperoleh oleh Friskianti(2014) yang menyatakan bahwa Self Assessment System tidak berpengaruh terhadap tindakan penggelapan pajak, namun tidak sejalan dengan hasil penelitian yang diperoleh oleh Saraswati(2013) yang menunjukkan bahwa Self Assessment System berpengaruh terhadap Tax Evasion. Secara teori, semakin diterapkannya Self Assessment System, maka akan semakin tinggi tindakan penggelapan pajak. Akan tetapi, berdasarkan hasil yang diperoleh peneliti, dapat dibuktikan jika sistem pemungutan pajak di Indonesia yang dianut saat ini, yaitu Self Assessment System telah berjalan dengan baik, hal ini bisa dilihat dari hasil rata-rata setiap pernyataan yang ada di uji statistik deskriptif adalah sebesar 4,22. Namun, hal tersebut tidak dijadikan sebagai kesempatan bagi Wajib Pajak untuk melakukan tindakan penggelapan pajak dalam hal menghitung, membayar, dan melaporkan sendiri besarnya jumlah pajak yang terutang. Oleh karena itu, dengan menerapkan Self Assessment System, maka tidak akan mempengaruhi persepsi Wajib Pajak untuk melakukan tindakan penggelapan pajak.

\section{Pengaruh Pelayanan Aparat Pajak terhadap Persepsi Wajib Pajak atas Penggelapan Pajak}

Berdasarkan tabel 11, dapat diketahui jika variabel pelayanan aparat pajak memiliki nilai signifikansi sebesar 0,001 yang artinya lebih kecil dari 0,05 . 
Selain itu, jika dilihat dari analisis model regresi linier berganda, variabel pelayanan aparat pajak memiliki koefisien regresi sebesar 0,458 yang menunjukkan arah positif dengan penggelapan pajak. Sehingga, dapat dikatakan bahwa variabel pelayanan aparat pajak berpengaruh positif terhadap persepsi Wajib Pajak atas penggelapan pajak. Dengan kata lain, hipotesis yang menyatakan bahwa pelayanan aparat pajak berpengaruh terhadap persepsi Wajib Pajak atas penggelapan pajak dapat diterima.

Hasil yang diperoleh peneliti menunjukkan bahwa pelayanan aparat pajak berpengaruh positif terhadap penggelapan pajak. Selain itu, jika dilihat dari hasil rata-rata seluruh pernyataan yang ada di uji statistik deskriptif, variabel pelayanan aparat pajak memiliki nilai ratarata 4,19. Hal ini juga menunjukkan bahwa Wajib Pajak tersebut telah berpersepsi bahwa pelayanan yang diberikan oleh aparat pajak telah baik, namun kenyataannya mereka tetap terindikasi memiliki keinginan untuk melakukan penggelapan pajak. Hasil penelitian ini berlawanan dengan Yetmi(2014) yang menyatakan bahwa kualitas pelayanan pajak tidak berpengaruh terhadap persepsi Wajib Pajak mengenai penggelapan pajak dan berlawanan secara arah dengan penelitian yang dilakukan oleh Rachmadi(2014) yang menyatakan bahwa pelayanan aparat pajak berpengaruh negatif terhadap penggelapan pajak. Menurut teori, memang seharusnya pelayanan aparat pajak memberikan pengaruh yang negatif terhadap penggelapan pajak. Perbedaan antara teori dengan hasil yang didapat mungkin disebabkan karena saat ini beberapa Wajib Pajak lebih memilih alternatif lain daripada harus mendatangi Kantor Pelayanan Pajak dan berhadapan langsung dengan aparat pajak. Hal ini dapat dibuktikan dari adanya beberapa Wajib Pajak yang mulai memanfaatkan keberadaan elektronik, diantaranya dengan melakukan penyampaian SPT secara elektronik yang dapat dilakukan melalui website Direktorat Jenderal Pajak atau website Penyalur SPT Elektronik(eFilling), melakukan pembayaran pajak secara elektronik menggunakan Kode
Billing(e-Billing), dan membuat faktur pajak melalui aplikasi atau sistem elektronik yang ditentukan dan/atau disediakan oleh Direktorat Jenderal Pajak (e-Faktur)(Sumber:

www.pajak.go.id). Sehingga, meskipun pelayanan yang diberikan oleh aparat pajak telah sangat baik, namun tidak menutup kemungkinan jika Wajib Pajak akan tetap melakukan penggelapan pajak karena mereka sudah tidak begitu mempedulikan lagi mengenai baik atau tidaknya pelayanan aparat pajak, karena adanya alternatif fasilitas elektroknik untuk mengurus kewajiban perpajakannya. Bagi mereka yang terpenting adalah membayar pajak sekecil mungkin.

\section{Kesimpulan Dan Saran}

\section{Kesimpulan}

Berdasarkan hasil pengujian, keadilan dan pelayanan aparat pajak berpengaruh terhadap persepsi Wajib Pajak atas penggelapan pajak. Sedangkan, Self Assessment System tidak berpengaruh terhadap persepsi Wajib Pajak atas penggelapan pajak.

\section{Saran}

Peneliti selanjutnya diharapkan tidak hanya membatasi penelitian hanya pada satu wilayah saja. Hal ini dikarenakan, selama proses pencarian responden, peniliti mengalami cukup kesulitan untuk menemukan responden yang bersedia untuk mengisi kuesioner dan untuk diajak berfoto bersama sebagai bukti. Sehingga, butuh waktu lebih lama lagi untuk berkeliling menemukan responden yang langsung bersedia untuk berpartisipasi. Jika penelitian dilakukan di beberapa wilayah, otomatis akan semakin banyak lagi jumlah Wajib Pajaknya, sehingga tidak menutup kemungkinan akan lebih cepat dan mudah dalam proses pencarian responden. Dengan begitu, tidak dibutuhkan waktu yang lama untuk mengumpulkan seluruh responden yang diperlukan.

Selain itu, perlu dilakukan sosialisasi bagi para Wajib Pajak mengenai pentingnya untuk melakukan kewajiban perpajakan mereka dengan benar dan sosialisasi mengenai dampak yang akan dikenakan kepada Wajib Pajak apabila mereka terbukti atau ketahuan melakukan penggelapan 
pajak. Hal ini perlu dilakukan agar tindakan penggelapan pajak dapat dihindari, sehingga pada akhirnya tidak akan menimbulkan kerugian bagi negara.

\section{Daftar Pustaka}

Annan, B., Bekoe, W., \& Amponsah, E. N. (2013). Determinants of Tax Evasion in Ghana: 1970-2010, 6(3), 97-121.

Ardyaksa, T. K., \& Kiswanto. (2014). Pengaruh Keadilan, Tarif Pajak, Ketepatan Pengalokasian, Kecurangan, Teknologi dan Informasi Perpajakan terhadap Tax Evasion. Accounting Analysis Journal, 3(4), 475-484. https://doi.org/ISSN 2252-6765

Ayu, S. D. (2011). Persepsi Efektifitas Pemeriksaan Pajak terhadap Kecenderungan Melakukan Perlawanan Pajak. Seri Kajian Ilmiah, 14(1).

Darmawan, Deni (2016), Metode Penelitian Kuantitatif, Bandung: PT Remaja Rosdakarya.

Friskianti, Y., \& Handayani, B. D. (2014). Pengaruh Self Assessment System, Keadilan, Teknologi Perpajakan, dan Ketidakpercayaan kepada Pihak Fiskus terhadap Tindakan Tax Evasion. Accounting Analysis Journal, 3(4), 543-552. https://doi.org/ISSN 2252-6765

Ghozali, Imam (2016), Aplikasi Analisis Multivariate Dengan Program IBM SPSS 23, Edisi 8, Semarang: Badan Penerbit Universitas Diponegoro.

Hartati, Neneng (2015), Pengantar Perpajakan, Bandung: CV Pustaka Setia.

Mardiasmo (2016), Perpajakan Edisi Terbaru 2016, Yogyakarta: Andi.

Mulyana, Deddy (2016), Ilmu Komunikasi: Suatu Pengantar, Bandung: PT Remaja Rosdakarya.

Pohan, Chairil Anwar (2014), Manajemen Perpajakan: Strategi Perencanaan Pajak \& Bisnis, Edisi Revisi, Jakarta: PT Gramedia Pustaka Utama.

Priyatno, Duwi (2017), Panduan Praktis Olah Data Menggunakan SPSS, Yogyakarta: Andi.
Pulungan, R. H. (2015). Pengaruh Keadilan, Sistem Perpajakan, dan Kemungkinan Terdeteksinya Kecurangan terhadap Persepsi Wajib Pajak mengenai Etika Penggelapan Pajak(Tax Evasion). Multiparadigma lecture2, 2(1), 1-14. https://doi.org/10.1017/CBO9781107415324 .004

Rachmadi, W., \& Zulaikha. (2014). Faktor-Faktor yang Mempengaruhi Persepsi Wajib Pajak Orang Pribadi atas Perilaku Penggelapan Pajak(Studi Empiris pada Wajib Pajak Terdaftar di KPP Pratama Semarang Candisari), 3(2), 1-9.

Rahayu, Siti Kurnia (2013), Perpajakan Indonesia: Konsep dan Aspek Formal, Yogyakarta: Graha Ilmu.

Rahman, Irma Suryani (2013), Skripsi: Pengaruh Keadilan, Sistem Perpajakan, Diskriminasi, dan Kemungkinan Terdeteksi Kecurangan terhadap Persepsi Wajib Pajak mengenai Etika Penggelapan Pajak(Tax Evasion), Jakarta: Universitas Islam Negeri Syarif Hidayatullah.

Republik Indonesia. 2009. Undang-Undang No. 16 Tahun 2008 Tentang Ketentuan Umum dan Tata Cara Perpajakan Sebagaimana Telah Beberapa Kali Diubah Terakhir dengan Undang-Undang Republik Indonesia Nomor 16 Tahun 2009.

Resmi, Siti (2017), Perpajakan: Teori dan Kasus, Jakarta: Salemba Empat.

Saraswati, V. A. (2013). Pengaruh Pemeriksaan Pajak dan Self Assessment System terhadap Tax Evasion(Survei Pada Kantor Pelayanan Pajak di Lingkungan Kanwil Jabar I), 1-15.

Silaen, C., Basri, Y. M., \& Azhari. (2015). Pengaruh Sistem Perpajakan, Diskriminasi, Teknologi dan Informasi Perpajakan Terhadap Persepsi Wajib Pajak Mengenai Etika Penggelapan Pajak (Tax Evasion). Jom FEKON, 2(2), 1-15.

Suminarsasi, W., \& Supriyadi. (2011). Pengaruh Keadilan, Sistem Perpajakan, dan Diskriminasi terhadap Persepsi Wajib Pajak mengenai Etika Penggelapan Pajak(Tax Evasion). SNA 15 Banjarmasin, 0-29.

Supadmi, N. luh. (2009). Meningkatkan Kepatuhan 
Wajib Pajak Melalui Kualitas Pelayanan. Jurnal Ilmiah Akuntansi Dan Bisnis, 4(2), 114. Retrieved from http://ojs.unud.ac.id/index.php/jiab/article/vi ew/2598/1809

Tabandeh, R., Jusoh, M., \& Zaidi, M. A. S. (2012). Estimating Factors Affecting Tax Evasion in Malaysia: A Neural Network Method Analysis. Prosiding Perkem VII, 2, 15241535.

Yetmi, Y. S., Darmayanti, Y., \& Muslim, R. Y. (2014). Faktor-Faktor yang Mempengaruhi Persepsi Wajib Pajak mengenai Penggelapan Pajak, 5(1), 1-15. https://www.kemenkeu.go.id/apbn2017

http://ketentuan.pajak.go.id/index.php?r=aturan/ri nci\&idcrypt $=\mathrm{oJqinZ}$ w\%3D

http://www.pajak.go.id/content/e-billing

http://www.pajak.go.id/content/pengumumantentang-pemberitahuan-down-time-aplikasie-nofa-dan-e-faktur-dan-peluncuran

http://www.pajak.go.id/content/penyampaiansurat-pemberitahuan-online-efiling

http://www.pajak.go.id/sites/default/files/UUKUP-001-13-UU\%20KUP\%20201300\%20Mobile.pdf 


\section{LAMPIRAN :}

\section{Tabel 1}

Hasil Statistik Deskriptif Keadilan

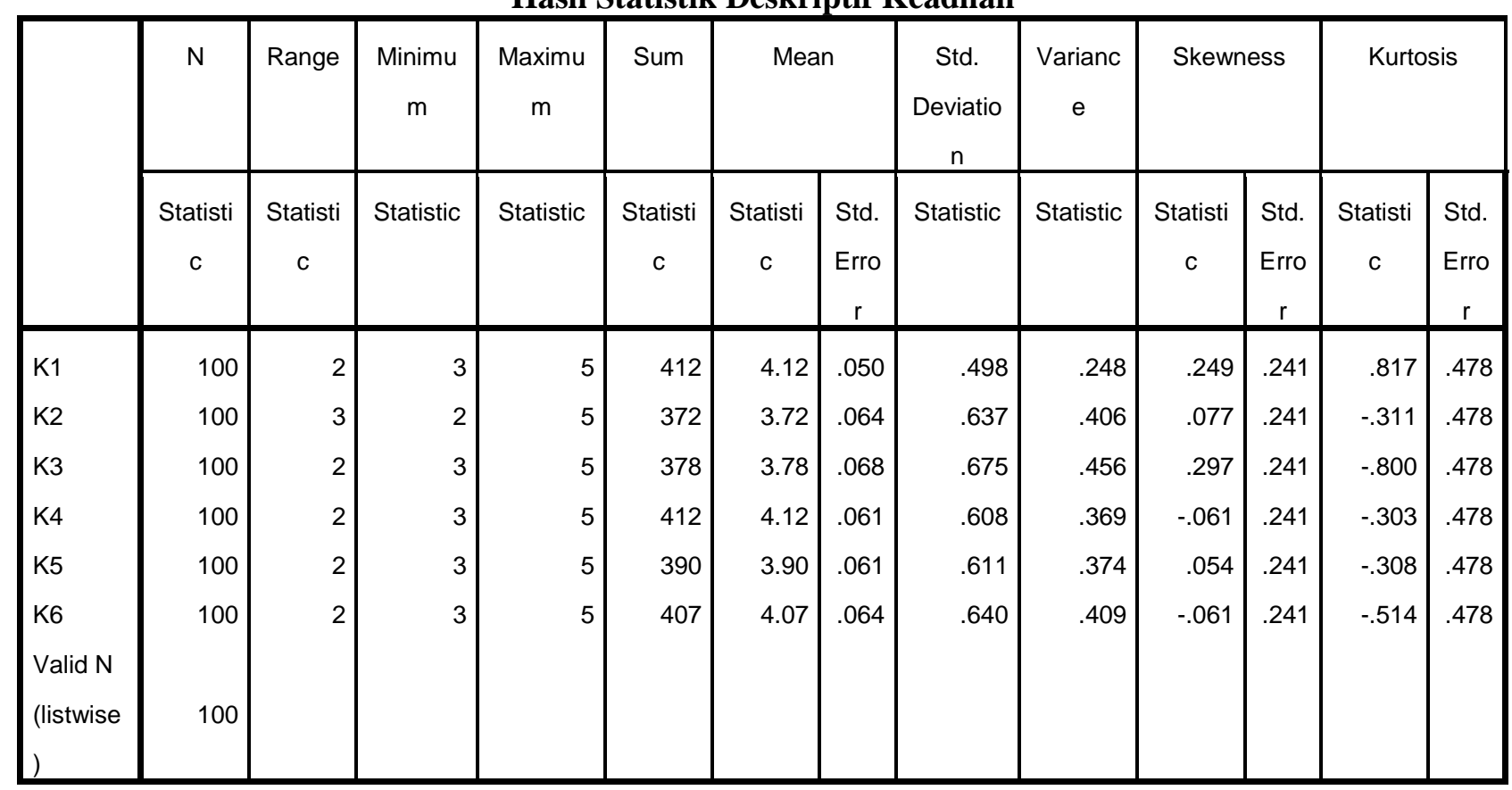

Sumber: Hasil Pengolahan Data pada SPSS

Tabel 2

Hasil Statistik Deskriptif Self Assessment System

\begin{tabular}{|c|c|c|c|c|c|c|c|c|c|c|c|c|c|}
\hline & $\mathrm{N}$ & Range & Minimu & Maximu & Sum & \multicolumn{2}{|c|}{ Mean } & \multirow{2}{*}{$\begin{array}{c}\text { Std. } \\
\text { Deviatio } \\
\mathrm{n} \\
\text { Statistic }\end{array}$} & \multirow{2}{*}{$\begin{array}{c}\text { Varianc } \\
\text { e } \\
\text { Statistic }\end{array}$} & \multicolumn{2}{|c|}{ Skewness } & \multicolumn{2}{|c|}{ Kurtosis } \\
\hline & $\begin{array}{c}\text { Statisti } \\
\text { C }\end{array}$ & $\begin{array}{c}\text { Statisti } \\
\text { c }\end{array}$ & Statistic & Statistic & $\begin{array}{l}\text { Statisti } \\
\text { C }\end{array}$ & $\begin{array}{c}\text { Statisti } \\
\text { c }\end{array}$ & $\begin{array}{c}\text { Std. } \\
\text { Erro } \\
r\end{array}$ & & & $\begin{array}{c}\text { Statisti } \\
\text { c }\end{array}$ & $\begin{array}{c}\text { Std. } \\
\text { Erro } \\
r\end{array}$ & $\begin{array}{c}\text { Statisti } \\
\text { c }\end{array}$ & $\begin{array}{c}\text { Std. } \\
\text { Erro } \\
r\end{array}$ \\
\hline SAS1 & 100 & 2 & 3 & 5 & 416 & 4.16 & .058 & .581 & .338 & -.024 & .241 & -.168 & .478 \\
\hline SAS2 & 100 & 2 & 3 & 5 & 393 & 3.93 & .066 & .655 & .429 & .072 & .241 & -.631 & .478 \\
\hline SAS3 & 100 & 2 & 3 & 5 & 412 & 4.12 & .054 & .537 & .288 & .103 & .241 & .359 & .478 \\
\hline SAS4 & 100 & 2 & 3 & 5 & 404 & 4.04 & .055 & .549 & .301 & .026 & .241 & .409 & .478 \\
\hline SAS5 & 100 & 2 & 3 & 5 & 430 & 4.30 & .048 & .482 & .232 & .607 & .241 & -.936 & .478 \\
\hline SAS6 & 100 & 1 & 4 & 5 & 443 & 4.43 & .050 & .498 & .248 & .287 & .241 & -1.957 & .478 \\
\hline SAS7 & 100 & 1 & 4 & 5 & 458 & 4.58 & .050 & .496 & .246 & -.329 & .241 & -1.931 & .478 \\
\hline Valid N & & & & & & & & & & & & & \\
\hline (listwise & 100 & & & & & & & & & & & & \\
\hline
\end{tabular}

Sumber: Hasil Pengolahan Data pada SPSS 
Tabel 3

Hasil Statistik Deskriptif Pelayanan Aparat Pajak

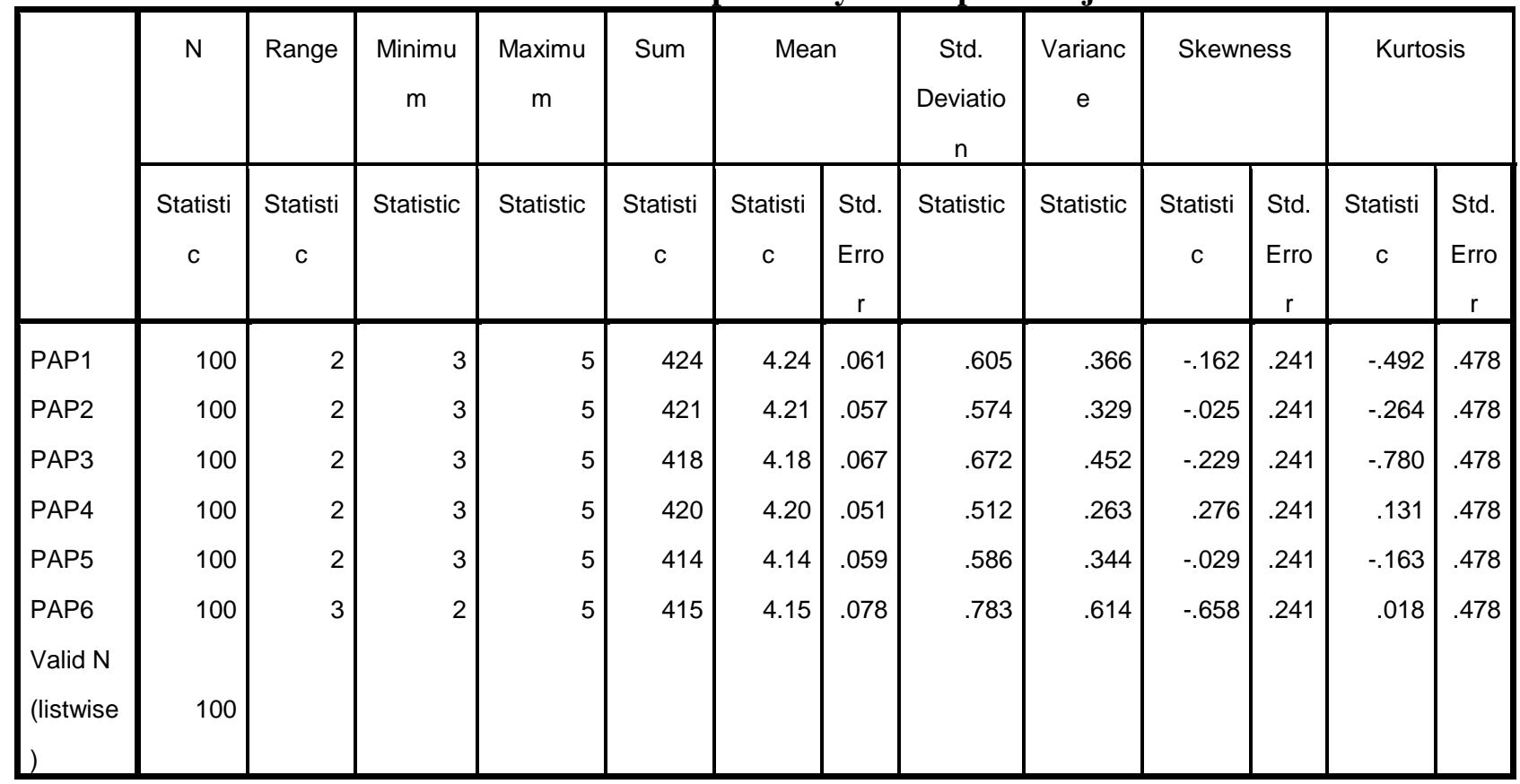

Sumber: Hasil Pengolahan Data pada SPSS

Tabel 4

Hasil Statistik Deskriptif Penggelapan Pajak

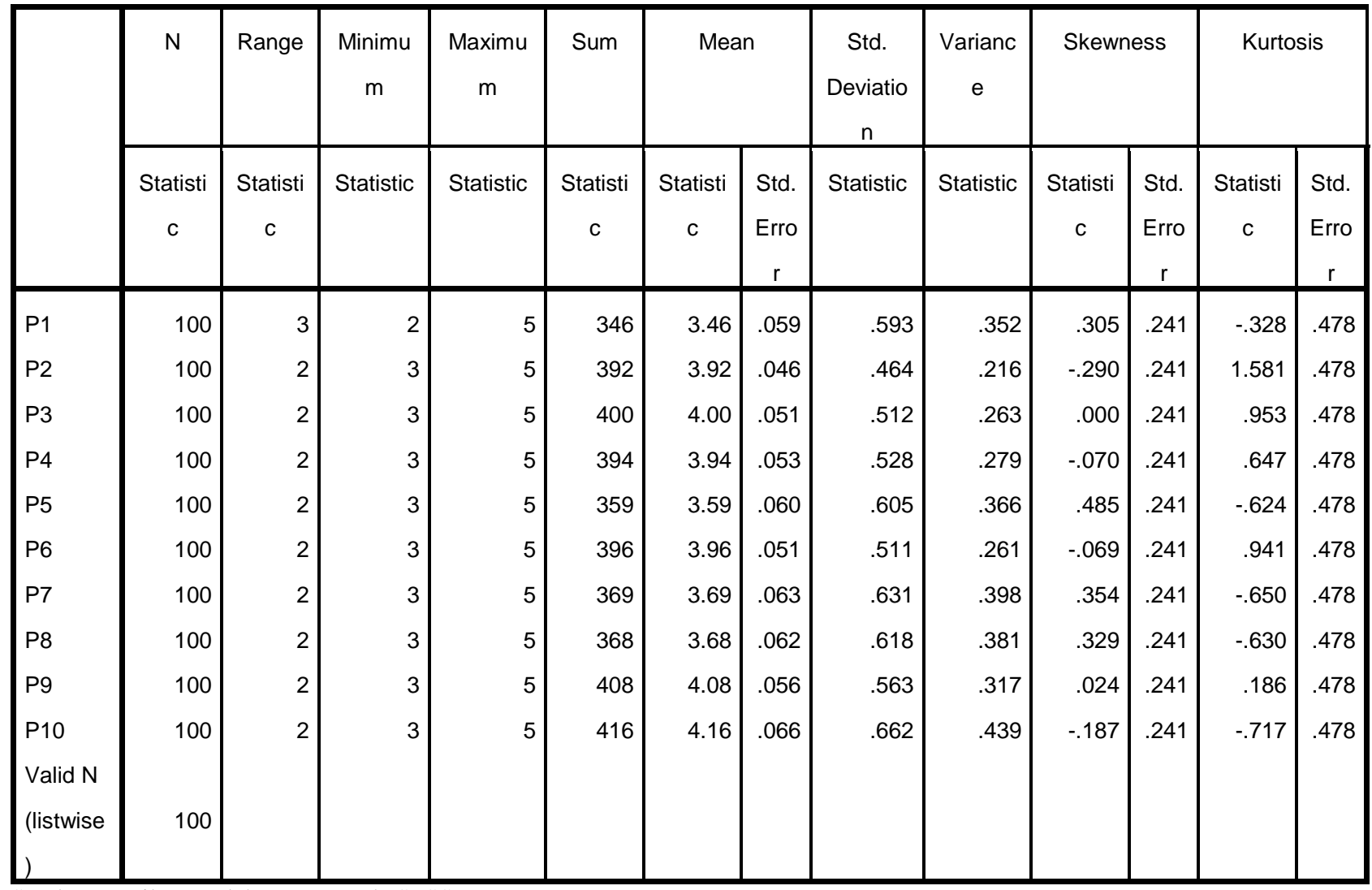


Tabel 5

Hasil Uji Multikolonieritas

\begin{tabular}{|l|c|c|c|}
\hline \multicolumn{1}{|c|}{ Variabel } & Tolerance & VIF & Keterangan \\
\hline Keadilan & 0,977 & 1,023 & Tidak ada multikolonieritas \\
\hline $\begin{array}{l}\text { Self Assessment } \\
\text { System }\end{array}$ & 0,970 & 1,030 & Tidak ada multikolonieritas \\
\hline $\begin{array}{l}\text { Pelayanan Aparat } \\
\text { Pajak }\end{array}$ & 0,951 & 1,052 & Tidak ada multikolonieritas \\
\hline
\end{tabular}

Sumber: Hasil Pengolahan Data pada SPSS

Tabel 6

Hasil Uji Autokorelasi

\begin{tabular}{|c|c|}
\hline Model & Durbin Watson \\
\hline 1 & 2,130 \\
\hline
\end{tabular}

Sumber: Hasil Pengolahan Data pada SPSS

Tabel 7

Hasil Uji Heteroskedastisitas

\begin{tabular}{|l|c|}
\hline \multicolumn{1}{|c|}{ Variabel } & Sig. \\
\hline Keadilan & 0,051 \\
\hline Self Assessment System & 0,664 \\
\hline Pelayanan Aparat Pajak & 0,069 \\
\hline
\end{tabular}

Sumber: Hasil Pengolahan Data pada SPSS

Tabel 8

Hasil Uji Normalitas

\begin{tabular}{|l|l|}
\hline Asymp. Sig. (2-tailed) & 0,284 \\
\hline
\end{tabular}

Sumber: Hasil Pengolahan Data pada SPSS

Tabel 9

Hasil Uji Koefisien Determinasi

\begin{tabular}{|c|c|}
\hline Model & Adjusted $\boldsymbol{R}$ Square \\
\hline 1 & 0,176 \\
\hline
\end{tabular}

Sumber: Hasil Pengolahan Data pada SPSS

Tabel 10

Hasil Uji Fisher(F)

\begin{tabular}{|c|c|}
\hline Model & Sig. \\
\hline Regresi & 0,000 \\
\hline
\end{tabular}

Sumber: Hasil Pengolahan Data pada SPSS 
Tabel 11

Hasil Uji Statistik t

\begin{tabular}{|l|c|}
\hline \multicolumn{1}{|c|}{ Variabel } & Sig. \\
\hline Keadilan & 0,003 \\
\hline Self Assessment System & 0,737 \\
\hline Pelayanan Aparat Pajak & 0,001 \\
\hline
\end{tabular}

Sumber: Hasil Pengolahan Data pada SPSS

Tabel 12

Analisis Model Regresi Linier Berganda

\begin{tabular}{|l|c|c|}
\hline \multirow{2}{*}{\multicolumn{1}{|c|}{ Variabel }} & \multicolumn{2}{|c|}{ Unstandardized Coefficients } \\
\cline { 2 - 3 } & B & Std. Error \\
\hline (Constant) & 18,057 & 5,407 \\
\hline Keadilan & 0,427 & 0,139 \\
\hline Self Assessment System & $-0,041$ & 0,122 \\
\hline Pelayanan Aparat Pajak & 0,458 & 0,138 \\
\hline
\end{tabular}

Sumber: Hasil Pengolahan Data pada SPSS 